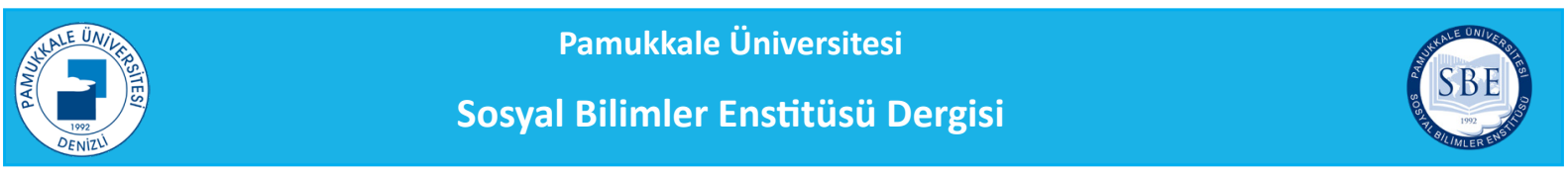

Pamukkale University Journal of Social Sciences Institute

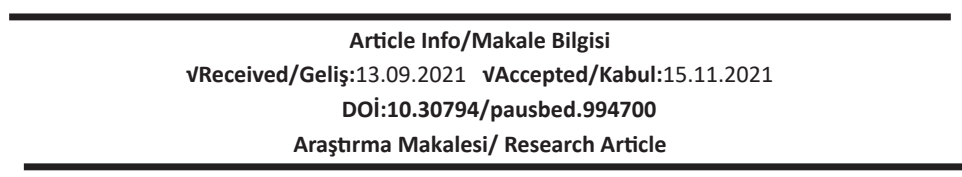

Özdemir Akcan, E. ve Sütütemiz, N. (2022). "Analysis of Brand Perceptions of Covid-19 Vaccines By Sentiment Analysis on Social Media",Pamukkale University Journal of Social Sciences Institute, Issue 49, Denizli, ss. 145-162.

\title{
ANALYSIS OF BRAND PERCEPTIONS OF COVID-19 VACCINES BY SENTIMENT ANALYSIS ON SOCIAL MEDIA
}

\author{
Emel ÖZDEMIR AKCAN*, Nihal SÜTÜTEMIZ**
}

\begin{abstract}
The increasing use of communication networks have facilitated to communication between brands and social media users, and users and brands have become closer in terms of sharing their thoughts. However, this use has also revived the need to analyze many ideas and thoughts. There is increasing curiosity and uncertainty in the public regarding the treatment of COVID-19 which concerns the entire world, in addition to concerns about which vaccine brand will be more effective and what the outcomes will be. In this study, it was aimed to reveal the perspectives of social media users about these vaccines and through Sinovac and BioNTech brands using text analysis. In the examination of COVID-19 vaccines within the scope of the study, text mining, which is a qualitative research method was performed. All tweets posted on the microblogging site Twitter about the BioNTech and Sinovac vaccines were interpreted using the sentiment analysis technique for the period between 15 March 2021 and 15 April 2021. In the analysis, it was ensured that the interpretations of vaccines were classified with R programming language as positive, negative or neutral. According to the obtained results, the attitudes of users towards the BioNTech brand were neutral, and the brand was perceived to be more trustworthy than the Sinovac brand in the comments shared.
\end{abstract}

Keywords: Brand Image, COVID-19 Vaccines, Social Media, Sentiment Analysis, $R$.

\section{COVID-19 AŞILARININ MARKA ALGILAMALARININ SOSYAL MEDYA ÜZERINDEN DUYGU ANALIZI ILE INCELENMESI}

Öz

İletişim ağları kullanımının giderek hız kazanması markaların sosyal medya kullanıııları ile iletişimini kolaylaştırmış, kullanıcılar ile markalar düşünce paylaşımı açısından yakınlaşmışlardır. Bununla birlikte birçok fikir ve düşüncenin analiz edilmesi ihtiyacını da gündeme getirmiştir. Kamuoyunda, tüm dünyayı ilgilendiren Covid-19 tedavisine yönelik hangi aşı markasının daha etkili olacağı ve sonucunun ne olacağına ilişkin sağlık endişelerinin yanı sıra artan bir merak ve belirsizlik bulunmaktadır. Bu çalışmada, sosyal medya kullanıcılarının bu aşılara bakış açıları ve bahsi geçen iki markaya karşı çağrışımları henüz yeni bir yöntem olan metin analizi tekniği kullanılarak BioNTech ve Sinovac markaları üzerinden ortaya konmaya çalışımıştı. Böylece, hem henüz yeni yeni kullanılmaya başlanan söz konusu yöntemin kavranmasıyla ilgili metodolojik bir katkı hem de aşı markalarının imajına etki eden unsurların ne olduğuna dair özetleyici bilgi sunmak hedeflenmiştir. Çalışma kapsamındaki Covid-19 aşılarının incelenmesinde nitel araştırma yöntemlerinden metin madenciliği yapılarak, 15 Mart 2021 ile 15 Nisan 2021 tarihleri arasında, mikro-blog sitesi olarak kullanılan Twitter aracılığı ile BioNTech ve Sinovac aşıları ile ilgili tüm tweetler duygu analizi tekniği ile yorumlanmıştı. Analizde, aşılara ait yorumların pozitif, negatif veya nötr olarak R programlama dili ile sınıflandırılması sağlanmıştır. Elde edilen sonuçlara göre, paylaşılan yorumlarda BioNTech markasına ait tutumların nötr olduğu ve Sinovac markasına göre daha güvenli olarak algılandığı bulunmuştur.

Anahtar Kelimeler: Marka Imajı, Covid-19 Aşıları, Sosyal Medya, Duygu Analizi, R.

* PhD Candidate, Sakarya University, Graduate School of Business, SAKARYA.

e-mail: emelozdemir83@hotmail.com, (https://orcid.org/0000-0003-2068-5265)

**Assoc. Prof., Sakarya University, MIS Department, Faculty of Business, SAKARYA.

e-mail: nihals@sakarya.edu.tr, (https://orcid.org/0000-0002-8964-7198) 


\section{INTRODUCTION}

A pandemic is a public health problem affecting the entire world. It deeply affects individuals socially, economically and culturally at times and countries where it is experienced heavily. SARS-CoV-2 (COVID-19) is a virus that first broke out in the city of Wuhan in China's Hubei province with respiratory symptoms such as fever, cough and shortness of breath at the end of 2019 (Ministry of Health, 2020).

It is known that the disease caused by the SARS-CoV-2 virus, which was stated as the novel coronavirus disease - 2019 (COVID-19) at the beginning of January 2020, was first transmitted from animals to humans in China, and it then spread all over the world including Europe and the Americas. The World Health Organization (WHO) declared COVID-19 as a global pandemic. Accordingly, the pandemic infected 247.472.724 individuals in 212 countries and caused over 5.012.337 deaths (WHO Coronavirus, 2021).

It is foreseen that concerns about the treatment of the COVID-19 pandemic and its impact on societies will continue for a while. Unfortunately, it is predicted that the pandemic will spread rapidly, and the numbers of people affected by the pandemic will continue to increase because of globalization. While the pandemic has caused the death of many people, it has also brought radical changes and inconveniences in daily life. The COVID-19 pandemic has reached a dangerous threat level that concerns the entire world. The world's agenda includes uncertainties about whether the pandemic can be brought under control, how it can be treated, and when it can end (Atay, 2020, p.169).

While searching for a vaccine to prevent infection with the SARS-CoV-2 virus and an effective drug to treat it definitively, preventive health services, as well as studies on drugs and vaccines against the disease, continue. There has been a general expectation that the pandemic will be treated by implementing an effective and trustworthy vaccination policy in society. Many countries have stepped up their clinical research activities to develop an effective vaccine against COVID-19. Approximately 200 vaccines developed for the effective treatment of the COVID-19 pandemic have begun to be clinically tested (Ullah et al., 2021, p.1). The number of COVID-19 infections is increasing exponentially, and there is a high level of public debate about finding a vaccine that is thought to reduce the spread of the disease.

With the COVID-19 pandemic being effective all over the world, much information and many thoughts about whose accuracy we are not sure have been shared, and it has become increasingly difficult to get trustworthy news about this pandemic. In this sense, information pollution on the topic in the media has led to increasing concern and panic in society regarding vaccination activities. Due to the measures taken to prevent people's mobility because of the COVID-19 pandemic, social media platforms have maintained their importance as an effective tool in conveying the public's curiosity, concerns and developments related to health news. To share health-related information and news during the pandemic period, Twitter has become one of the important channels in both following the current agenda closely and conveying one's thoughts and feelings. The information pollution in the media regarding research on vaccine development for the pandemic causes individuals to have hesitations about vaccination and which vaccine brand they should use, while it can cause healthcare workers to have a difficult time while administering vaccines (Ayaz, 2020, p.49).

Which vaccine brand is more effective and trustworthy in the prevention of the disease is being discussed in Turkey as in the rest of the world. This busy agenda and increasing curiosity have brought about the need to analyze many ideas and thoughts.

To analyze posts shared by social media users about vaccine brands, it is necessary to interpret the sentiments of the people in the text content and the intensities of these sentiments mathematically. In the analysis of big data on social media, especially the text mining method is used. This study also adopted the text mining method. Text mining is a relatively new field of computer science, and its use has grown as the available unstructured data continues to grow exponentially in both relevance and quantity. Text mining can be used to make large amounts of unstructured data accessible and useful (Işık, 2019, p.16). It is a technological research method that aims to extract useful information hidden in text content through techniques such as classification, entity extraction, sentiment analysis and others from unstructured texts (He, Zha, \& Li, 2013, p.465). 
In this study, it is aimed to reveal the brand images and attitudes of users regarding COVID-19 vaccine brands on Twitter, a micro-blog site, between 15 March and 15 April 2020. In terms of original contribution, this study not only provides a methodologically different analytical perspective to researchers in branding, but also offers an opportunity to explore consumer perceptions related to the BioNTech and Sinovac brands, the two vaccine brands used in Turkey, as well as the impact they have on people.

The sentimental intensities of tweet contents were determined through the available Twitter API using the $R$ program within the scope of the research. For each text that was sent in the form of a tweet, an analysis was made based on the sentimental aspect of the text, the sentiment score of the text and the sentiment-related words. The NRC dictionary developed by Mohammad \& Turney (2013) was used, in which negative words were scored as -1 , positive words were scored as 1 , and neutral words were scored as 0 , and eight different emotions were included.

\section{SOCIAL MEDIA}

The internet is a universally used communication tool through which many electronic devices are interconnected, and the number of its users is increasing day by day.

The web has revealed the phenomenon of social media where users can communicate via easy-to-use programs and platforms (Akın \& Şimşek, 2018, p.799). Social media channels are some of the most important information-sharing networks where users communicate with each other on the internet.

Social media, which offers fast, inexpensive and practical use, has become one of the most preferred communication channels of the current century (Öztürk \& Talas, 2015, p.113).

According to the We Are Social (2021) October report, there are 4.55 billion social media users, which make up $57.6 \%$ of the world's population, and 60 million social media users in Turkey, which make up $71 \%$ of the country's population (We Are Social, 2021). While these figures show the widespread use of social media, they also make this digital medium a relevant field of research. It is asserted that social media is not just a communication tool but offers important strategies for policy, news, health, agenda and brand practices. Moreover, it is observed that social media is preferred to communicate more intensely in times of social crises. For example, the "2011 August events" in the United Kingdom, the "Arab Spring ", the 2013 Boston Marathon Explosion" (Altunbaş, 2014, p. 5), the "2013 Gezi Park events" in Turkey, the "Occupy Wall Street movement, "I Can't Breathe demonstrations" (2014, USA), "Humanity Washed Ashore" (2015, Turkey), the "July 15 coup attempt" (2016, Turkey), the "Baltimore protests" (2017, USA), the "California earthquake in 2016", the "Yellow vests protests" (2018, France), the "uprising attempt against Maduro" (2019, Venezuela), and the "George Floyd protests" (2020, USA) are main examples that have taken their place on social media which is used commonly by scientists (Karakoç \& Taydaş, 2020). Similarly, it is seen that the use of social media has increased with the COVID-19 pandemic that emerged in China at the end of 2019. According to the report prepared by Social CRM and Adba Analytics, together with the Brand Age Magazine, based on the period of January 21 - March 112020 , the number of posts shared by social media users worldwide about COVID-19 exceeded 275 million. 6,506,597 posts were shared between the specified dates in Turkey, which ranks 10th in the ranking of the countries with the highest number of shares. Additionally, COVID-19 is related to the health sector among the sectors that have become prominent in worldwide shares, and implementing vaccination programs to prevent the spread of the disease is among matters that are prominent on the basis of health in worldwide shares (Indyturk, 2020). It is clear that social media is increasingly becoming a preferred communication tool among both individuals and decision-makers.

Social media platforms may be distinguished from each other based on their functions. This study focused on content posted on Twitter, which is used as a microblog platform.

Twitter is only one of the social media tools used today. The changing structure and form of communication have provided the momentum of the Twitter platform. Founded in the US in 2006, Twitter is a microblogging site that offers users the opportunity to follow current events with constantly updated and renewed news and at the 
same time express their opinions through tweets posted using a maximum of 280 characters. Twitter, which is a groundbreaking and digital social space in social communication, has been actively used by 397 million people in the world according to 2021 data (Statista, 2021). While the country that uses Twitter most in the world is the United States of America with 73 million users, Turkey ranks 7th in the list with 15.6 million users (We Are Social, 2021).

Twitter is not only limited to providing information but also functions as an effective communication tool in social movements with its capacity to provide fast information flow. "One of the important features of Twitter is that it can affect individuals and audiences economically, psychologically, socially, culturally and politically and mobilize them on various issues in a short time. Having a communication network on this level is an important feature for Twitter to be popular as a communication platform" (Öke, 2018, p.56). In general, research has contributed to the understanding of Twitter's public power and potential. Thus, today, Twitter is being used as an effective communication platform in many fields such as diplomacy, politics, election campaigns, street actions, health, agenda, and brands. In this sense, it has been seen not only as a news source but also as an alternative media channel where everyone can report (Gülcan \& Bayram, 2021, p.38).

Therefore, people prefer social media platforms they see as trustworthy as a channel of obtaining and disseminating information when they face social events and serious health threats such as a pandemic. Social media performs an important function in providing social communication with numerous forums and content related to information about such events (Şenol \& Avcl, 2019, p. 53).

\section{RELATIONSHIP BETWEEN BRAND IMAGE AND SOCIAL MEDIA}

The image of a brand is the set of associations and attributes that the consumer has adopted regarding the brand name. These associations can be functional, tangible and emotional features such as trustworthy, exciting, fun, boring, or innovative. To evaluate the brand image besides qualities such as what the brand symbolizes in the customer's mind and what it makes one think, the customer's purchasing orientation should also be considered. Each product is targeted to be identified with a brand, and each brand assumes the position of the qualifier of that product. When the brand image, which is built based on a certain quality, loses the quality of that product, this image can be damaged by causing negative consequences such as losing reliability (Karpat, 1990 pp. 86-87 cited in Özüpek, 2004, pp. 103-104).

In this sense, social media platforms have the potential power to improve the brand and brand image of businesses (Aaker, 2015, p.112).

Research has shown that there is a strong interaction between social media and brand. In other words, in the online survey conducted by InSites Consulting on 9027 people in 2011, it was revealed that $50 \%$ of social network users had a connection with a brand, experiences related to a brand were expressed mostly in online conversations, and in this context, $36 \%$ of the themes on social platforms were related to brands. It was emphasized that social media comprises comments about brands, and consumers now prefer social networks instead of e-mail to ask questions, advise, complain and report about their satisfaction to a brand (InSites, 2011).

Social media channels appear as environments that can meet the needs of businesses so that brands can see the place they create in the consumer's mind and strengthen their brand position in the consumer's mind. This is because consumers can make comments freely about products and services for a brand, share their opinions and ideas and make recommendations and complaints in these environments. In this sense, consumers come to an active position by leaving their passive position and can determine the brand images of firms as positive or negative. Additionally, by reflecting the position of the brand identity in the customer's mind, social media users can reveal the differences of the brand from its competitors (Uraltaş \& Bahadırlı, 2012, p. 41).

The presence of a new target audience interacting via social networks offers businesses the opportunity to see and manage their positive and negative qualities in areas such as competition analysis, image management, strategic positioning, public relations, and brand management. Moreover, consumers have the opportunity to follow brands more closely and position them more prominently in their minds through digital platforms (Aydın, 
2017, p. 327). It is possible to determine the images of the COVID-19 vaccines in use in Turkey in the user's mind and consumer attitudes towards these vaccines by analyzing user activity on social networks.

\section{STATUS OF COVID-19 VACCINE BRANDS IN THE WORLD AND IN TURKEY}

Vaccine development studies for the COVID-19 pandemic started from the first stages of the spread of the disease. From January 2020 to November 2021, 129 vaccines with different contents and production techniques have been subjected to laboratory tests, and 28 of these vaccines are in Phase III, which is the final one among the generally accepted testing phases. Furthermore, development activities continue around the world for 194 candidate vaccines. As vaccine development work continues, over 247.472 .724 people have been reported to be infected in the world, and the need for a vaccine with a high impact on the disease has increased (WHO Covid-19, 2021). It is foreseen that it will not be enough to create COVID-19 vaccines, which are still in progress, on a level that will meet needs and distribute them to the world. In countries where the vaccine is distributed, the issue of which groups in society will have the priority to get the vaccine has also brought up problems that are discussed in terms of morals and health. Additionally, there is not enough scientific information about the effects and results of vaccines. The organization named COVAX, which is formed by the World Health Organization and includes non-governmental organizations, provides services for the delivery of COVID-19 vaccines to the world on a fair and sufficient level. Thus, it is predicted that $40 \%$ of the population in countries will be vaccinated by the end of 2021. Although it is predicted that global vaccination will be very effective in slowing down and controlling the pandemic, it is not thought to annihilate the SARS-CoV-2 virus. There are serious uncertainties about whether vaccines will be sufficient in personal treatment, on which populations they will be effective and how effective they will be, the duration of their protection, and their side effects (Azap, 2020, pp.98-99).

In the fight against the COVID-19 pandemic across Turkey, Health Minister Fahrettin Koca signed the first vaccine contract on 3 December 2020. CoronaVac which has been developed by Sinovac, the first vaccine brand originating in China, was also the first vaccine brand planned to be implemented in Turkey. It reached Turkey on 25 December 2020. Another vaccine brand that was planned to be applied in Turkey is the BioNTech vaccine launched by Pfizer in the US and BioNTech in Germany. Health Minister Fahrettin Koca signed a usage agreement on 25 December 2020 and announced that it would arrive in Turkey on 18 March 2021 (Ministry of Health, 2020). There are 10 brands of COVID-19 vaccines that are currently being tested around the world to make them ready for application. These are the UK-based Astra-Zeneca (Oxford University), Turkey based Turkovac (Erciyes University- TUSEB), the US-based Moderna (US National Institute of Health (NIH)), the Germany-US-based Pfizer and BioNTech, the US-based Janssen (Johnson \& Johnson), the Russia-based Gamaleya (National Research Center, Medical Sciences Military Academy), the Chinese CanSino (Military Academy of Biology Medical Sciences), the Chinese Sinovac (Biotechnology), the Chinese Sinopharm (Wuhan Institute of Biological Products), the Chinese Sinopharm (Beijing Institute of Biological Products), and the India-based Novavax (Bharat Biotechnology). In Turkey, in the first place, CoronaVac vaccines produced by China and BioNTech vaccines produced in the USGermany have been put into use (Azap, 2020 p. 99). The production of domestic vaccines Turkovac has started in Turkey. It has been Phase III stage and clinical tests are still ongoing.

Most of the population in Turkey still has confusion and hesitations about which vaccine brand is more effective and safer. For this reason, this study was planned to determine perceptions on COVID-19 vaccine brands, which occupy the minds of society.

\section{RELATED WORKS}

Some examples of recent studies on the sentiment analysis of Twitter datasets on different topics related to the COVID-19 pandemic are as follows.

Xue et al. (2020) collected four million units of Twitter data on COVID-19 by using 25 different hashtags for the period between 1 March 2020 and 21 April 2020. For topic modeling and sentiment determination in tweets posted by Twitter users, they utilized the machine learning method known as Latent Dirichlet Allocation (LDA) with the unigram and bigram approaches. They used the NRC Sentiment Lexicon to categorize sentiments into eight main sentiments. The results they obtained showed that Twitter users displayed fear rather than trust while tweeting about COVID-19 cases or deaths. 
Vijay et al. (2020) conducted a study on categorizing the sentiments of the Indian public based on cities in the COVID-19 pandemic period. They categorized 250,000 tweets they obtained using the Twitter API for sentiment analysis as positive, negative and neutral with the Python analysis tool.

Boon-Itt and Skunkan (2020) investigated the attitudes of the public towards the COVID-19 pandemic by using the sentiment analysis and topic modeling approaches. They obtained 107,990 units of Twitter data for the period from December 2019 to March 2020. Using the Python and RStudio analysis tools, they determined that the most intensely experienced sentiment among the public regarding the pandemic was fear. With the topic modeling method, the pandemic period was modeled under 3 headings as emergency, how to control COVID-19 and reports on COVID-19.

Dubey (2020) aimed to determine how citizens of each country coped with the COVID-19 pandemic period using tweets collected for 12 countries. They constructed a Twitter dataset using RStudio. They concluded that citizens of France, the US and the Netherlands displayed the sentiments of distrust and anger as more negative sentiments than those generally displayed in the other countries that were examined.

Kamaran et al. (2020) examined the sentiments of Twitter users in a 7-day period as negative, positive and neutral. They collected 530,232 tweets posted in the period between 9 April 2020 and 15 April 2020 by using the Python platform. They compared the data obtained by using the COVID-19 and coronavirus key phrases based on which key phrase was used. According to their findings, the polarity of user comments for both key phrases was neutral.

Villavicencio et al. (2021) focused on sentiment analysis with the natural language processing (NLP) method to analyze the reactions of the public in COVID-19 vaccine-related tweets shared from the Philippines. The authors used the RapidMiner data science software with $81.77 \%$ accuracy, utilized the Naïve Bayes model to classify tweets posted in English and the local languages (993 tweets) and presented the sentiments of the Filipino people regarding COVID-19 vaccines.

Chaudhri et al. (2021) investigated whether or not people accepted getting a COVID-19 vaccine. They performed a sentiment analysis on a dataset consisting of 900 tweets. Their results showed that people generally had a weakly positive view about getting COVID-19 vaccines.

Sattar and Arifuzzaman (2021) conducted an analysis on public awareness about COVID-19 vaccination and its aftermath in relation to health and safety precautions. They utilized the methods of sentiment analysis and time series-based prediction. According to the results they obtained on tweets posted in English, people had positive sentiments about getting COVID-19 vaccines despite some adverse effects of some vaccines. Their prediction models projected that approximately $62.44 \%$ of the US population would have received at least one dose of a vaccine, $48 \%$ would have been fully vaccinated until the end of July 2021.

Sanders et al. (2021) used the sentiment analysis method to investigate Twitter data related to facemasks. They observed that the number of tweets about facemasks and the polarity of the sentiments of these tweets increased substantially from 17 March 2020 to 27 July 2020. They also used clustering methods to collect these tweets under fifteen sets and fifteen subsets under each topic. Moreover, they applied an abstractive text summarization model using NLP to automatically interpret and define the topic of discourse in each set and subset.

As seen in the literature review in this study, the number of studies that have focused on Twitter data regarding brand images for COVID-19 vaccines among previous sentiment analysis studies is highly limited.

\section{METHOD}

The aim of this study is to examine how the vaccine brands developed for protection and started to be implemented in Turkey during the COVID-19 pandemic, which affects the entire world population, are perceived throughout Turkey and how they create an image. In this context, it was aimed to find answers to the questions of what is talked about COVID-19 vaccines in Turkey, which vaccine brand is found the most trustworthy, towards 
which brand people have a more positive attitude, and what feelings social media users have towards these brands. For this purpose, an analysis was conducted on the posts (tweets) of Twitter users in Turkey on the topic. In the study, sentiment analysis was carried out by using text analysis, a qualitative research method, in the examination of tweets.

The concept of sentiment analysis is an approach that aims to reveal the components of attitudes and opinions that are hidden in the datasets where people reveal their attitudes and thoughts about brands, companies, products, services, people, places, events and many similar subjects (Liu, 2020 pp. 1-2). Attitudes indicated by a piece of text are subjected to classification processes through various methods. A word is graded as negative, positive or neutral and classified according to whether the text-based data, paragraphs, sentences or words a unit of analysis contains have a positive or negative meaning. Sentiment classification techniques are generally considered in three basic categories: machine learning approach, lexicon-based approach and hybrid approach. In this study, the lexicon-based approach was adopted. This approach was selected because it does not require algorithmic coding and large amounts of data compared to machine learning approaches, and it can also be used for research in the social sciences. Additionally, the RStudio analysis software was preferred due to its easy-tounderstand and applicable interface, its performance in large-volume datasets and its effective results in text mining.

The study was carried out at six stages. First, the Twitter microblogging network was used to obtain tweets about the vaccine brands Sinovac and BioNTech that are used in Turkey. Between 15 March 2021 and 15 April 2021, a total of 21,676 tweets were collected from Twitter users regarding the vaccine brands "BioNTech" and "Sinovac". The data set were collected from twitter users which was shared from Turkey location and in Turkish language. The data collection step was taken using the Twitter API. In the second step, the obtained data were preprocessed using the RStudio program. In the third step, the data that were cleared were divided into frequencies, and the most frequently used words in the tweets were determined. In the fourth step, the data whose frequencies were determined were matched with the NRC sentiment lexicon developed by Muhammad and Turney (2013) in the RStudio program, and word-level sentiment analysis was performed. The sentimental aspect of each entity was scored as negative $(-1)$, positive $(+1)$ or neutral $(0)$, and the prominent sentiment words were classified as "positive", "negative" or "neutral". In the fifth step, the tweets for both vaccine brands were grouped on the document level with the method of sentiment aspect clustering. Finally, the collected tweets were grouped into clusters based on the emotional attitudes of the social media users who had posted these tweets.

\section{FINDINGS}

\subsection{Data Extraction}

During the data extraction phase, tweets shared between 15 March 2021 and 15 April 2021, when there were uncertainties regarding vaccine development and the use of vaccines in Turkey, were obtained through the Twitter API. Tweets that were posted in Turkish and by users located in Turkey were focused on. The "ROAuth", "rtweet" and "twitterR" libraries in the R programming software were used to access the Twitter API. Data with the date and number allowed by R and the Twitter API were collected using the keywords "Sinovac" and "BioNTech". The tweets related to these brands were named and recorded separately as datasets. A total of 20,277 units of data belonging to the Sinovac brand and 1,399 data units belonging to the BioNTech brand were recorded as corpus files.

\subsection{Dataset Preprocessing}

The cumulative Twitter sentiment analysis dataset of the Sinovac and BioNTech brands contained 21,676 tweets. The content of the dataset collected as text was filtered using the " $\mathrm{tm}$ ", "tidytext" "tidyvers" "dplyr" and "magrittr" libraries on the RStudio platform. First of all, the numbers, symbols and punctuation marks in the data were removed. 
Table 1: Removed Data

\begin{tabular}{|l|l|l|l|l|l|}
\hline $\begin{array}{l}\text { Removed } \\
\text { Characters }\end{array}$ & Substitutes & $\begin{array}{l}\text { Removed } \\
\text { Characters }\end{array}$ & Substitutes & $\begin{array}{l}\text { Removed } \\
\text { Characters }\end{array}$ & Substitutes \\
\hline$\ldots \ldots .$. & Space & $!$ & Space & https & Removed \\
\hline$\cdot$ & Space & J & Space & @ & Removed \\
\hline$?$ & Space & 50 & Removed & but & Removed \\
\hline$:$ & Space & 1 & Space & $\begin{array}{l}\text { Locative } \\
\text { cases }\end{array}$ & Removed \\
\hline
\end{tabular}

Then, capital letters were converted to lowercase letters, and all words were case-sensitized. Phrases formed by less than 3 words which are not express emotion were removed from the dataset. Examples of characters and words that were considered unnecessary for the analysis and those accepted as appropriate to be removed are given in Table 1.

\subsection{Identifying Word Frequencies}

In order to obtain meaningful and valuable results at the sentiment analysis stage, it is important that the words that are used show sentiment. In sentiment analysis studies in the English language, these words are called stop words. For example, words like "me", "all of them", "anyway", "these" and "but" do not express any emotion. Such words were identified and discarded from the final dataset. The tweet text data belonging to the Sinovac and BioNTech brands were separated into two datasets of words. 414,790 words pertaining to the Sinovac brand were reduced to 25,830 words after the removal step. The same processes were applied to the BioNTech brand data, and finally, the initially collected 28,828 words were reduced to 7,537 words. To be able to conduct sentiment analysis using the NRC (Mohammad \& Turney, 2013) lexicon, after determining the most frequently used Turkish words, these words were translated to English.

In the top 30 most frequently used words obtained from the review of the BioNTech vaccine brand, words generally related to health concerns were included. The words BioNTech and vaccine were the first 2 most frequently used words in terms of being related to the topic. Users shared information about their vaccination preferences and vaccination appointments. It may be stated that users were curious about the dose, effect and virus protection of the vaccine. Additionally, there were words about what the side effects of the vaccine could be. These words consisted of "arm", "heart", "pain" and "allergy". The results are visualized in Figure 1.

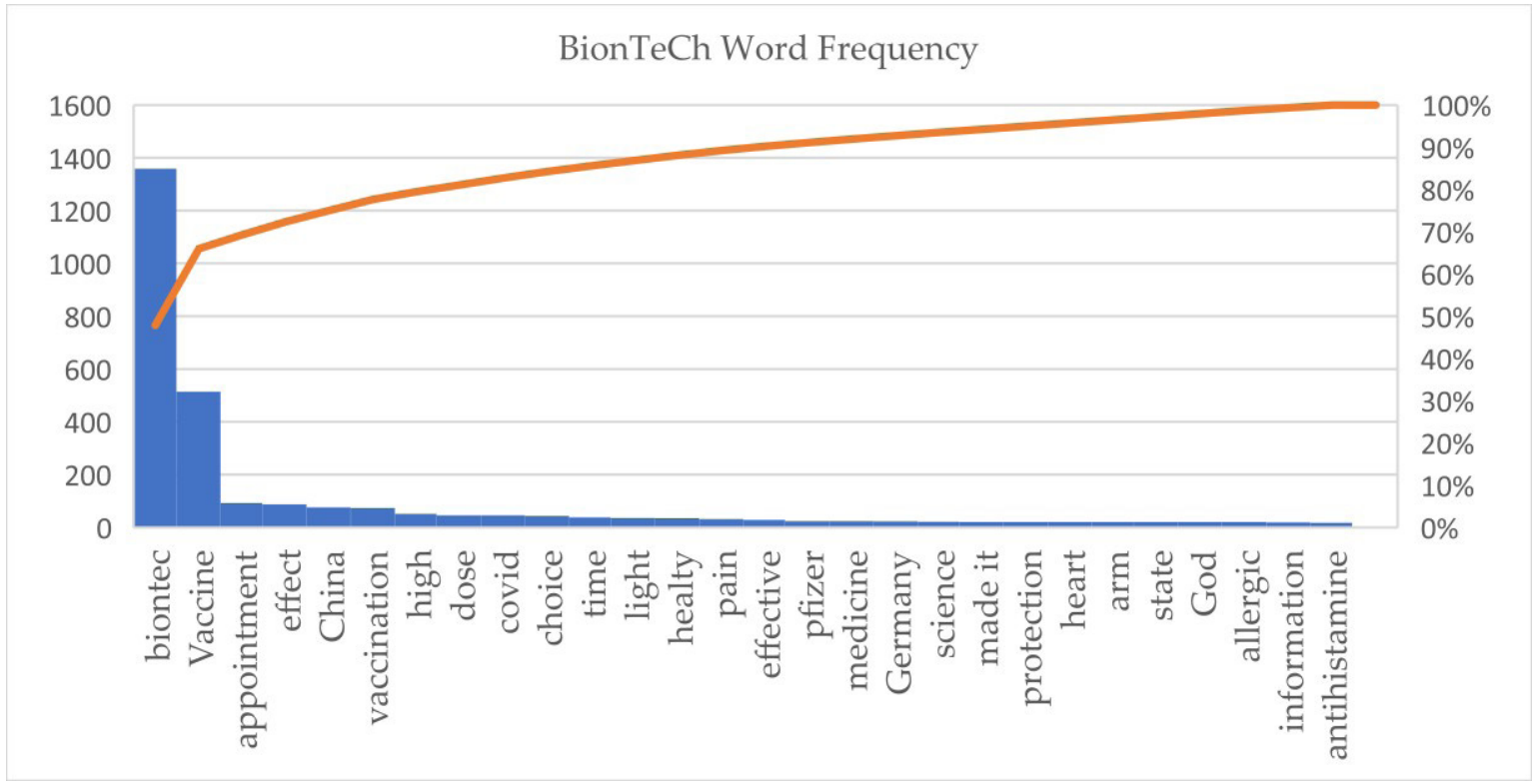

Figure 1: The 30 Most Frequently Used Words in Tweets Related to the BioNTech Brand 
As seen in the findings of the Sinovac brand shown in Figure 2, the words Sinovac, vaccine, BioNTech, China and Covid were commonly used. It was seen that the word BioNTech was the most frequently used word in the collected tweets. About Sinovac, it may be inferred that there were uncertainties about the selection preferences of users related to the two vaccine brands, and users shared their information. Moreover, words such as health, effect, protection, phase and antibody and thoughts on the protection level of the vaccine brand against the virus were shared. It may also be stated that the words high, mild, pain and dose expressed the curiosity or concern of users in terms of usage levels and potential side effects.

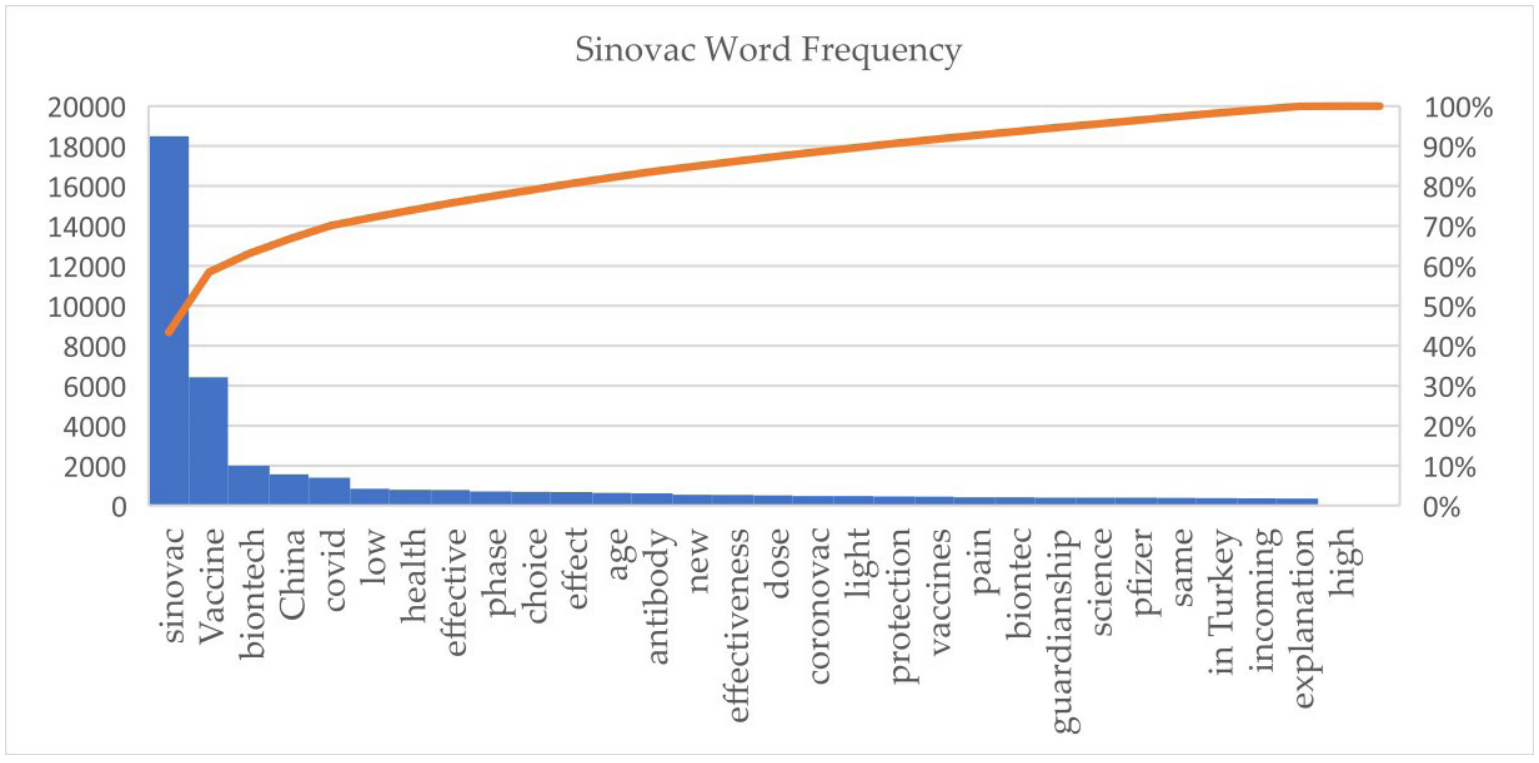

Figure 2: The 30 Most Frequently Used Words in Sinovac Brand Tweets

\section{4. Vocabulary Level Sentiment Analysis}

Analyses on two different levels were carried out for the sentiment analysis of the data obtained using the Twitter API. These levels were the word (entity) level and the document (text) level. The word-level sentiment analysis approach is the process of understanding what emotion or thought is expressed with a word by rating the emotion of each word in a sentence. Document-level sentiment analysis, on the other hand, finds the overall sentiment of a text fragment by collecting individual sentiment scores for each word in the text to understand what emotion or thought is intended to be expressed with a piece of text. The overall user opinion, which consists of more than one sentence, is considered as a whole. While performing semantic analysis, firstly, words must be matched with appropriate objects from the database (Önden, Kiygi-Calli \& Okan 2018, p. 248). For this, a lexicon of sentiments with sentiment scores is needed. In our study, the NRC (National Research Council of Canada) lexicon containing 13,901 words, developed by Muhammad and Turney (2013) and known as the most comprehensive general sentiment lexicon was used. Sentiment analysis can be performed on the eight basic emotions in the NRC dictionary. These are anger, anticipation, disgust, fear, joy, sadness, surprise, and confidence. The sentiment equivalents of words in the NRC lexicon are graded with scores of 1, 0 and -1 . A score of 1 for a word shows a positive sentiment, a score of 0 shows a neutral sentiment, and a score of -1 shows a negative sentiment. Accordingly, the Sinovac and BioNTech datasets were separately combined with the "inner_ join" function on the R platform, and the word scores were matched. A total of 1,797 words were matched in the Sinovac dataset, and the sentiment polarities and frequencies of the first 30 words are shown in Table 2. In the BioNTech data, 776 words were matched, and the sentiment polarities and frequencies of the first 30 words are visualized in Table 3. Approximately $8 \%$ of the words in the tweets were found in the NRC lexicon. 
Table 2: Sinovac Tweets and the First 30 Words to Match with the NRC Lexicon

\begin{tabular}{|c|c|c|c|c|c|c|c|c|}
\hline Word & Frq. & Polarity & Word & Frq. & Polarity & Word & Frq. & Polarity \\
\hline Low & 845 & Negative & Effective & 781 & Positive & Vaccine & 6428 & Neutral \\
\hline Vaccine & 429 & Negative & Effect & 680 & Positive & Day & 1457 & Neutral \\
\hline Heavy & 330 & Negative & Protection & 461 & Positive & Side & 1163 & Neutral \\
\hline Virus & 287 & Negative & Important & 292 & Positive & Health & 797 & Neutral \\
\hline Chronic & 265 & Negative & Acceptance & 248 & Positive & Phase & 717 & Neutral \\
\hline Patient & 244 & Negative & Protector & 224 & Positive & Percentage & 704 & Neutral \\
\hline Pain & 239 & Negative & Doctor & 206 & Positive & Choice & 693 & Neutral \\
\hline Problem & 205 & Negative & Information & 181 & Positive & Age & 638 & Neutral \\
\hline Trouble & 178 & Negative & Next & 179 & Positive & Against & 598 & Neutral \\
\hline Death & 163 & Negative & Yes & 177 & Positive & New & 546 & Neutral \\
\hline Cancer & 155 & Negative & Option & 176 & Positive & Week & 519 & Neutral \\
\hline Mutant & 124 & Negative & Serious & 175 & Positive & Today & 503 & Neutral \\
\hline Bad & 123 & Negative & Research & 166 & Positive & Mild & 478 & Neutral \\
\hline Lie & 121 & Negative & Question & 163 & Positive & Time & 433 & Neutral \\
\hline Old & 120 & Negative & Result & 141 & Positive & High & 396 & Neutral \\
\hline Flu & 108 & Negative & Search & 123 & Positive & Same & 385 & Neutral \\
\hline Risk & 104 & Negative & Real & 113 & Positive & Incoming & 364 & Neutral \\
\hline Insufficient & 100 & Negative & Curiosity & 111 & Positive & Explanation & 360 & Neutral \\
\hline Mixed & 97 & Negative & Applied & 110 & Positive & Individual & 359 & Neutral \\
\hline Pandemic & 91 & Negative & Appropriate & 104 & Positive & Appointment & 359 & Neutral \\
\hline Risky & 89 & Negative & Beautiful & 103 & Positive & Continue & 329 & Neutral \\
\hline Negative & 82 & Negative & Traditional & 99 & Positive & End & 312 & Neutral \\
\hline Dangerous & 70 & Negative & Vitality & 97 & Positive & Output & 298 & Neutral \\
\hline Common & 65 & Negative & Selection & 97 & Positive & Disease & 275 & Neutral \\
\hline Indecisive & 61 & Negative & Maker & 94 & Positive & Different & 270 & Neutral \\
\hline Toxical & 61 & Negative & Technology & 87 & Positive & Situation & 266 & Neutral \\
\hline Indecisive & 61 & Negative & Healing & 85 & Positive & Dense & 259 & Neutral \\
\hline Extreme & 58 & Negative & General & 82 & Positive & Yesterday & 249 & Neutral \\
\hline Late & 58 & Negative & Authorized & 78 & Positive & Vaccination & 241 & Neutral \\
\hline Garbage & 55 & Negative & Agreement & 74 & Positive & Big & 239 & Neutral \\
\hline Complaint & 42 & Negative & Confirmation & 74 & Positive & Medicine & 237 & Neutral \\
\hline
\end{tabular}

In Tables 2 and 3, it is seen that the most frequently used negative words were related to the disease and the vaccine such as "Low", "Vaccine", "Heavy", "Virus", "Chronic", "Pain", "Problem" and "Death", which showed that words related to anxiety about the results were used frequently. When we look at the most frequently used positive words, words of expectation about the selection and effectiveness of the vaccines were dominant, and the neutral words included words that gave ideas about the current agenda. 
Table 3: First 30 Words to Match with BioNTech Tweets and NRC Lexicon

\begin{tabular}{|c|c|c|c|c|c|c|c|c|}
\hline Word & Frq. & Polarity & Word & Frq. & Polarity & Word & Frq. & Polarity \\
\hline Pain & 32 & Negative & Effect & 46 & Positive & Vaccine & 515 & Neutral \\
\hline Cancel & 28 & Negative & Effective & 29 & Positive & Day & 127 & Neutral \\
\hline Immediately & 23 & Negative & Doctor & 27 & Positive & Side & 105 & Neutral \\
\hline Problem & 17 & Negative & Protection & 21 & Positive & Appointment & 93 & Neutral \\
\hline Trouble & 15 & Negative & Information & 19 & Positive & Week & 46 & Neutral \\
\hline Low & 14 & Negative & Yes & 19 & Positive & Today & 45 & Neutral \\
\hline Lie & 13 & Negative & Acceptance & 13 & Positive & Choice & 44 & Neutral \\
\hline Risky & 12 & Negative & Option & 13 & Positive & Yesterday & 39 & Neutral \\
\hline Chronic & 11 & Negative & Protector & 11 & Positive & Time & 38 & Neutral \\
\hline Risk & 11 & Negative & Friend & 10 & Positive & Mild & 36 & Neutral \\
\hline Virus & 11 & Negative & Precious & 10 & Positive & Health & 35 & Neutral \\
\hline Between & 10 & Negative & Serious & 9 & Positive & Age & 33 & Neutral \\
\hline Dollar & 10 & Negative & Important & 9 & Positive & Human & 32 & Neutral \\
\hline Paralysis & 9 & Negative & Prevention & 9 & Positive & Individual & 32 & Neutral \\
\hline Cancer & 9 & Negative & Receive & 8 & Positive & Same & 29 & Neutral \\
\hline Mixed & 9 & Negative & Certain & 8 & Positive & High & 26 & Neutral \\
\hline Disabled & 8 & Negative & Search & 7 & Positive & Sir & 25 & Neutral \\
\hline Open & 7 & Negative & Respects & 7 & Positive & Medicine & 24 & Neutral \\
\hline Heavy & 6 & Negative & Alive & 6 & Positive & Output & 23 & Neutral \\
\hline Lower & 6 & Negative & Cure & 6 & Positive & People & 22 & Neutral \\
\hline Negative & 6 & Negative & Degree & 6 & Positive & Heart & 21 & Neutral \\
\hline Death & 6 & Negative & General & 6 & Positive & Arm & 21 & Neutral \\
\hline Pandemic & 6 & Negative & Real & 6 & Positive & Clock & 19 & Neutral \\
\hline Uncomfortable & 5 & Negative & Curiosity & 6 & Positive & Vaccination & 18 & Neutral \\
\hline Forcefully & 5 & Negative & Priority & 6 & Positive & Decision & 18 & Neutral \\
\hline Bad & 5 & Negative & Question & 6 & Positive & System & 15 & Neutral \\
\hline Stupid & 3 & Negative & Longing & 5 & Positive & End & 15 & Neutral \\
\hline Extreme & 3 & Negative & Providing & 5 & Positive & Morning & 13 & Neutral \\
\hline Excuse & 3 & Negative & Help & 5 & Positive & Long & 13 & Neutral \\
\hline Uncertain & 3 & Negative & Knowing & 4 & Positive & Brain & 10 & Neutral \\
\hline
\end{tabular}

According to the NRC lexicon, the sentiment values used more in the words used in the Sinovac and BioNTech brand tweets are shown in Figures 4 and 5, respectively. Accordingly, 400 (22\%) words were negative, 1,069 (59\%) words were neutral, and 328 (19\%) words were positive in terms of expressing opinions about the Sinovac brand. 


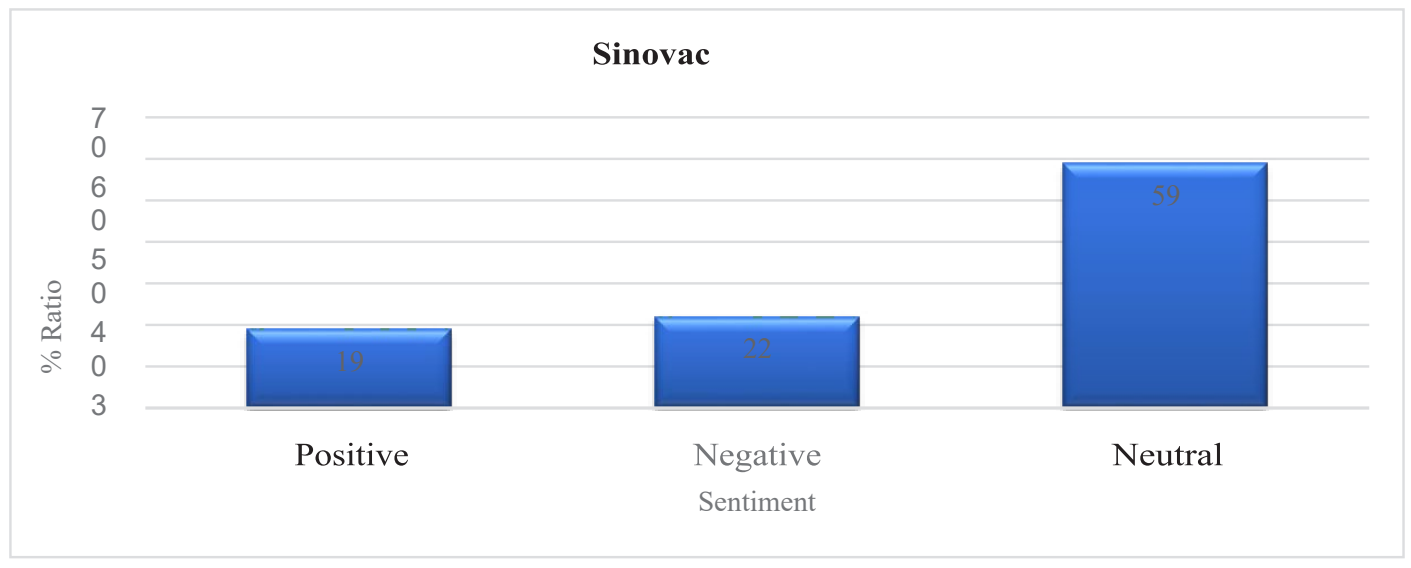

Figure 4: Distribution of Word Ratios by Sentimental Polarity (Sinovac)

When we look at the distribution of words used for the BioNTech brand, users used a total of 158 (20\%) negative words, 449 (58\%) neutral words and 169 (22\%) positive words while expressing their opinions about the brand in question.

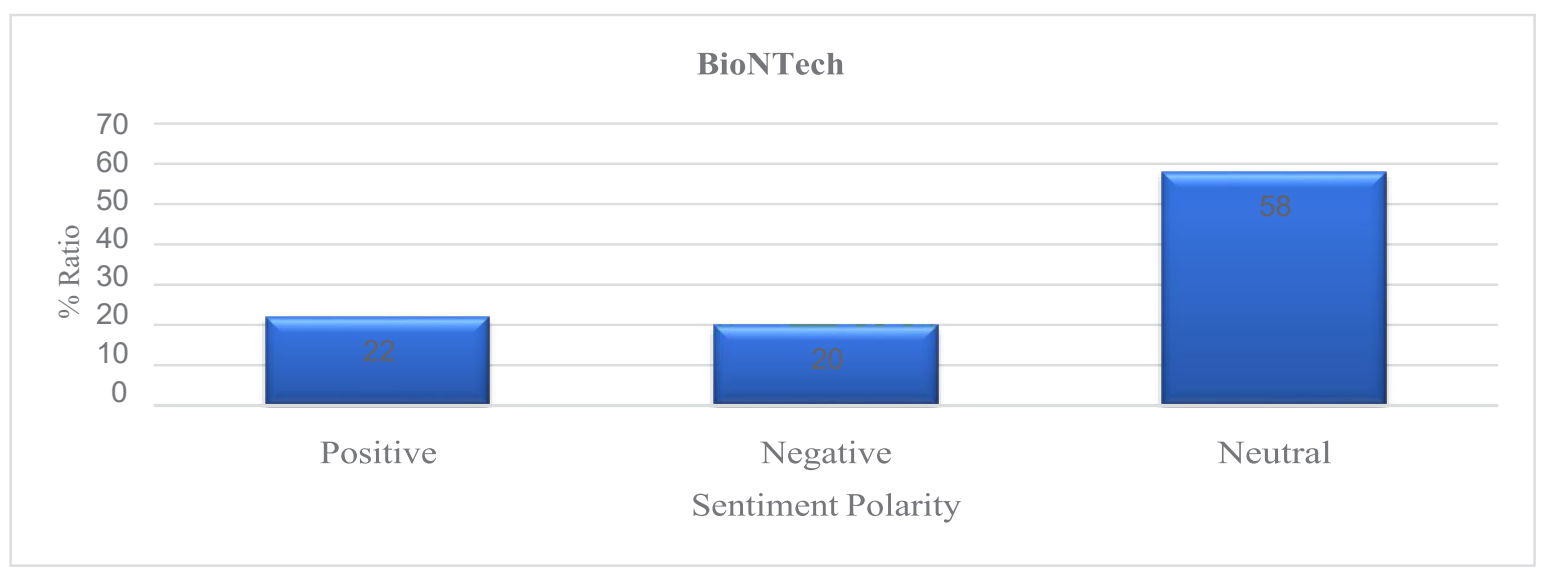

Figure 5: Distribution of Word Ratios by Sentimental Polarity (BioNTech)

The word-level sentiment analysis approach is considered the phase of determining the polarity of the sentiment to be expressed by a collection of words by rating the sentiment of each word in a sentence. According to the results of the sentiment analysis on the word level representing the fourth stage of the study, the Twitter posts of users showed a $3 \%$ more positive attitude towards the BioNTech brand in comparison to the Sinovac brand.

\section{5. Document (Sentence) Level Sentiment Analysis}

Based on the Sinovac and BioNTech data, the sentiment score of each tweet was determined by using the "tidytext" and "tidyverse" packages on the R platform to determine whether the user attitudes regarding brands or their images about the brands were positive or negative. The tweets shared by each user were subjected to sentiment analysis on the document level, and it was aimed to determine what the overall sentiment score of each tweet was. 


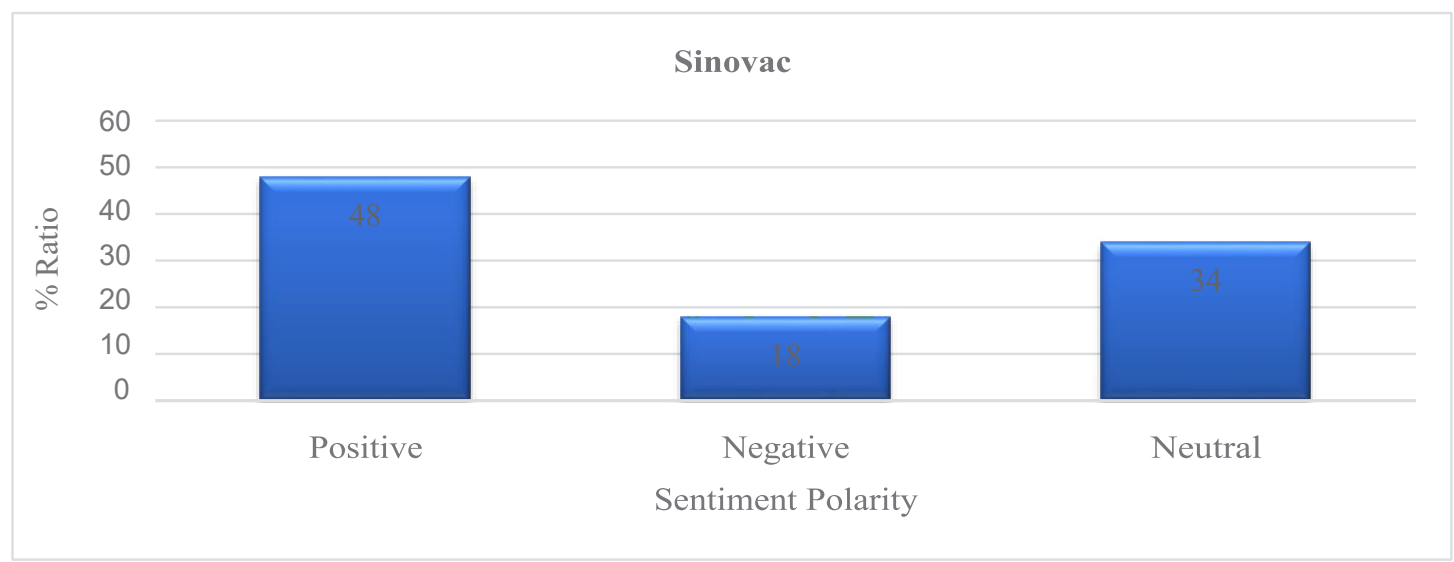

Figure 6: Sentiment Polarity Distribution of Sinovac Brand Tweets

Figure 6 shows the distribution of the sentiment polarities of the Sinovac brand on a document basis. Accordingly, 9,698 (48\%) of the 20,277 Sinovac tweets showed a positive attitude, while 3,738 (18\%) had a negative attitude. In 6,841 (34\%) tweets, a neutral attitude towards the brand was displayed.

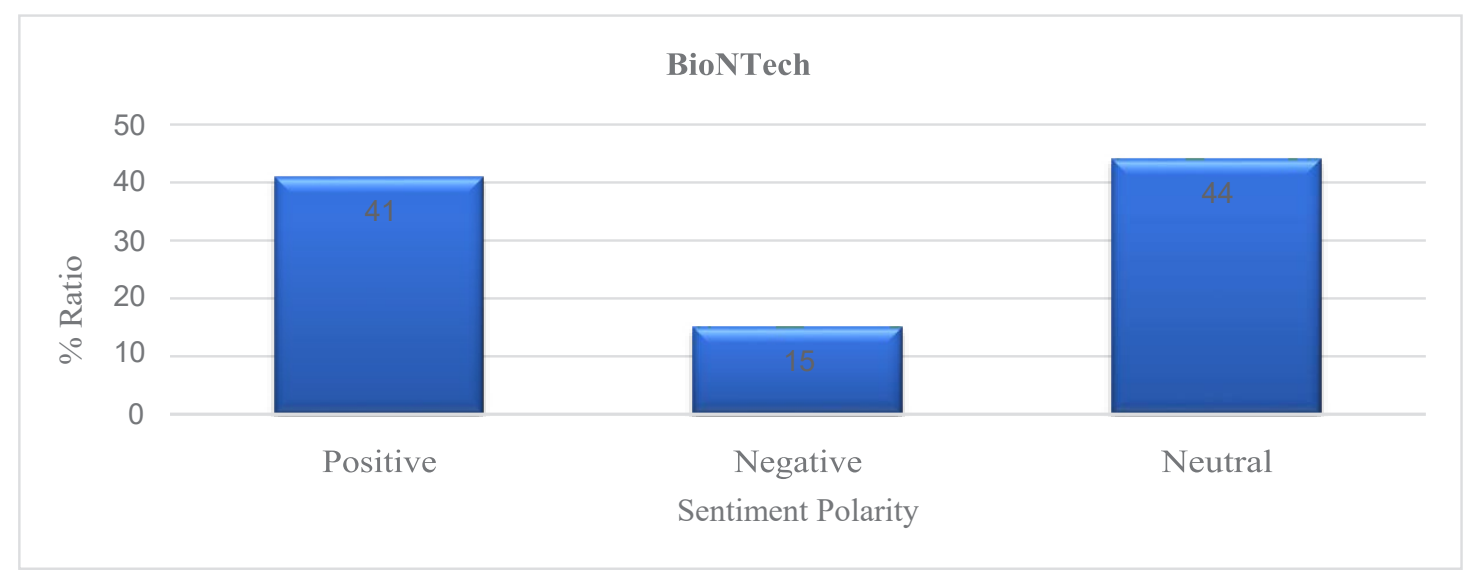

Figure 7: Sentiment Polarity Distributions of BioNTech Brand Tweets

As seen in Figure 7, regarding the tweets about the BioNTech vaccine brand, 569 (41\%) of users showed that they had a positive attitude by making positive comments, while 208 (15\%) of them made negative comments and had a negative attitude. Additionally, 622 (\%) users were found to have a neutral attitude. Based on these findings, one may state that Twitter users had a generally neutral attitude towards the use of the BioNTech vaccine brand.

\section{6. Analysis of User Sentiments According to Brands}

Within the scope of the NRC sentiment lexicon, there is a list of each word and its associations with specific categories of interest, such as emotions (e.g., joy, sadness, fear), attitudes (positive and negative) or colors (e.g., red, blue, black). Thus, it helps us eliminate large amounts of data and understand the content. For example, "What is said about a particular target entity?" as in Tables 2 and 3 (common target assets include a company, brand, product, policy, person, and country), or "Is the text about the target entity good or bad?" as in Figures 4-5 and Figures 6-7. Further sentiment analyses in the field of text analytics were also performed. This way, whether people are satisfied with, angry with or afraid of the goal can be revealed. It is possible to understand the basic sentiments in such texts more deeply. For this purpose, it was aimed to reveal what the basic sentiments of 
social media users about the two brands were based on the data obtained in this study. According to the analysis findings, the sentiments of fear and anger outweighed the other sentiments in the comments of users about the Sinovac brand, as seen in Figure 8.

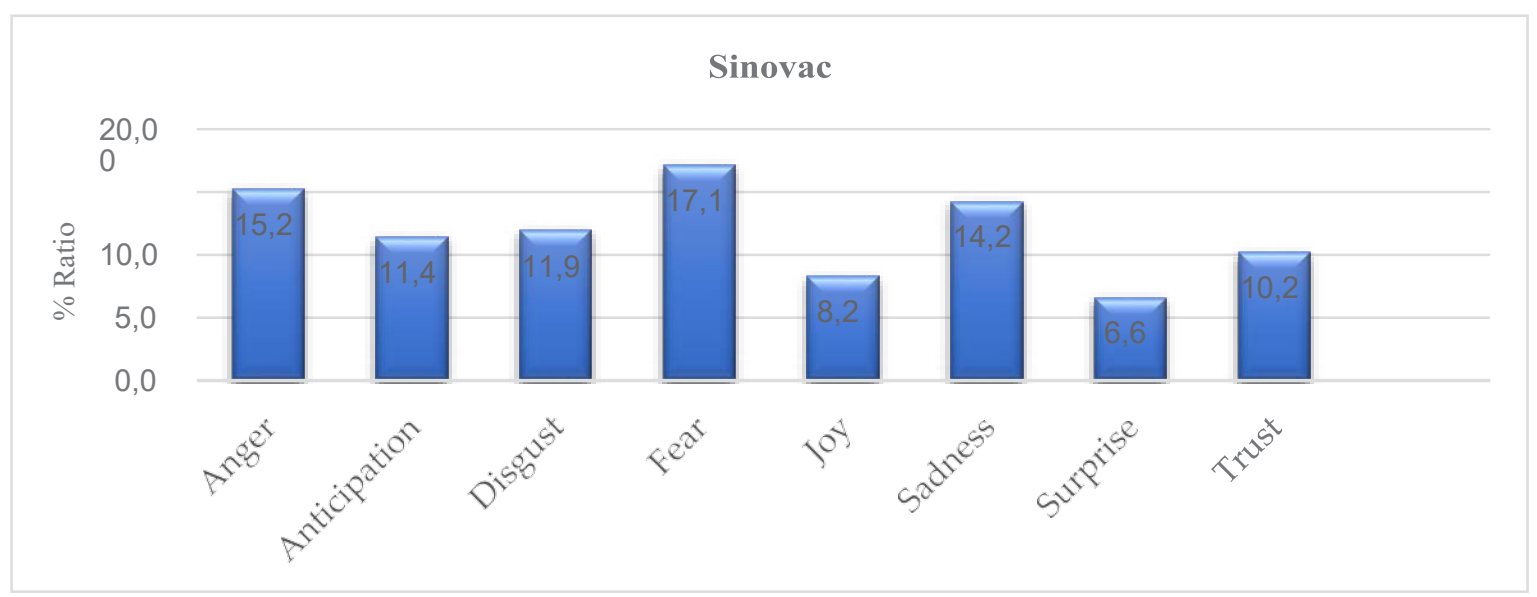

Figure 8: Distribution of Sentiments for the Sinovac Brand

It may be stated that there was anger against the brand in terms of the spread of the pandemic from China and the Sinovac brand being of Chinese origin, as well as fear and anxiety about the side effects that may occur due to the vaccine in the process of protection against the disease. The sentiment of sadness was also seen at a rate close to the sentiment of anger. The reason for this sadness may have been the uncertainty about the effectiveness of the vaccine and the resulting hopelessness. Considering the distribution of sentiments in general in the chart, negative emotions were more dominant than positive emotions.

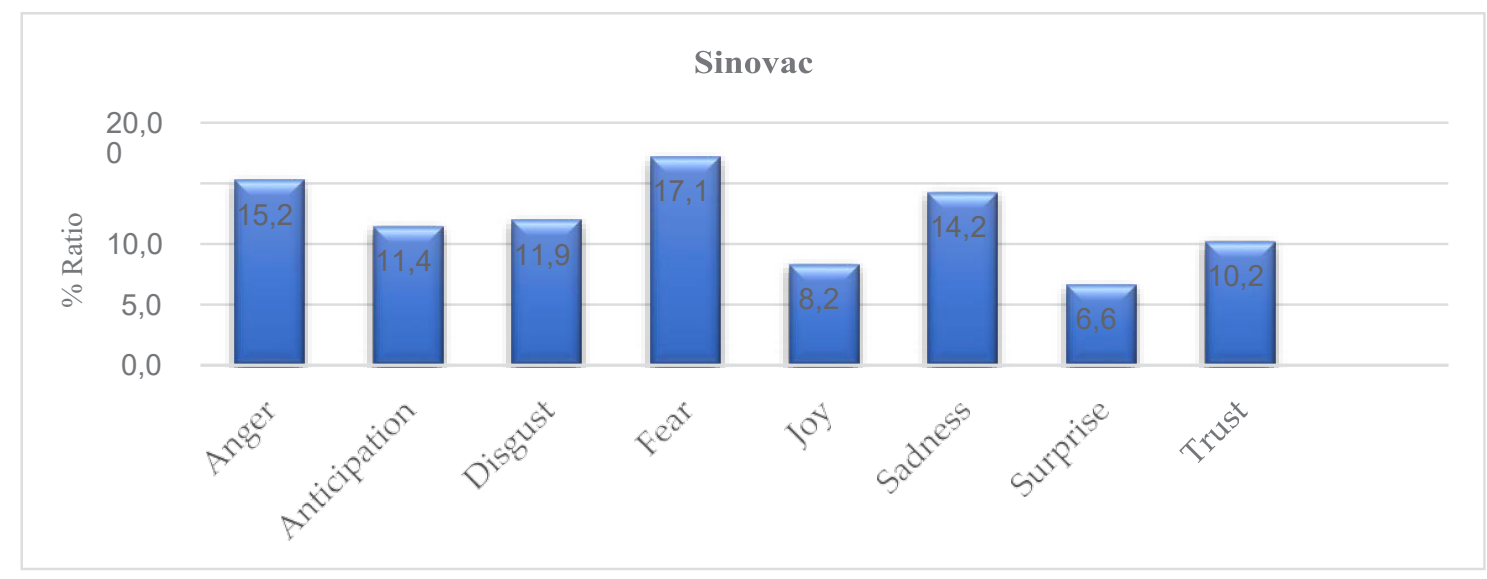

Figure 9: Distribution of Sentiments for the BioNTech Brand

In the tweets related to the BioNTech brand, the sentiment of trust was more common in comparison to other sentiments, and the sentiments of fear, sadness and anger had close distribution rates, as seen in Figure 9. The reason for trusting this brand may have been that it is of German origin, and it is thought to be more effective than the Chinese-origin brand, Sinovac. Moreover, the anger of users towards the process and the sentiment of fear brought about by uncertainty were also revealed in the tweets related to this brand. Considering the results given in the chart in general, it is possible to say that the majority of the tweets contained negative sentiments. 


\section{CONCLUSION AND RECOMMENDATIONS}

This study was carried out when uncertainties and debates about the two vaccine brands to be used within the scope of preventive health services during the COVID-19 pandemic period in Turkey were on the main agenda of the country. It was aimed to examine the attitudes and feelings of social media users towards the Sinovac and BioNTech brands. For this purpose, the sentiment analysis technique was used. Data extraction was carried out via Twitter, which is a social media platform. The obtained datasets were analyzed using the RStudio platform, which is commonly used in big data analysis with its ease of use and flexible structure. Table 4. summarizes the findings of this study.

Table 4. Tweets Data Set Summary

\begin{tabular}{|c|c|c|c|}
\hline & BioNTech & Sinovac & Total \\
\hline Total number of tweets in Turkish & 1,399 & 20,277 & 21,676 \\
\hline Number of words in the tweets & 28,828 & 414,790 & 443,618 \\
\hline Number of words after the preprocessing of the data & 7,537 & 25,830 & 33367 \\
\hline Number of words used in the sentiment analysis with the NRC lexicon & 776 & 1,797 & 2573 \\
\hline Total number of negative words & 158 & 400 & 558 \\
\hline Total number of positive words & 169 & 328 & 497 \\
\hline \multirow[t]{2}{*}{ Most frequently used negative word and its frequency } & Pain & Low & \multirow{2}{*}{877} \\
\hline & 32 & 845 & \\
\hline \multirow[t]{2}{*}{ Most frequently used positive word and its frequency } & Effect & Effective & \multirow{2}{*}{827} \\
\hline & 46 & 781 & \\
\hline
\end{tabular}

One of the main objectives of this study was to reveal the answer to the question of what users generally talked about vaccine brands. In the study, words such as "uncertain", "problem", "trouble", "risky", "death" and "pain" were among the most frequently expressed negative words in the tweets about both brands, which indicated that users were concerned about vaccination, and they were afraid. Positive words, on the other hand, appeared to consist of words such as "effect", "effective", "protective", "choice", "curiosity" and "remedy". It was seen that users emphasized their curiosity and expectations about the preferences and results of the vaccines with these words.

Regarding which brand had more positive attitudes or image, according to the results of the analysis of the included tweets on the word level, the neutral or unbiased sentiment statements for both brands were found at almost the same rates. At the same time, it was found that the tweets about the BioNTech brand contained $3 \%$ more positive words and $2 \%$ fewer negative words than the Sinovac brand. It is possible to say that the image of the BioNTech brand was more positive on a word basis. Additionally, according to the findings revealed as a result of the analysis on the document level, the rate of sentences containing a neutral attitude towards the BioNTech brand was $10 \%$ higher than that of Sinovac. This means that attitudes towards the Sinovac brand were more pronounced. In this context, while the rate of sentences containing positive sentiments was $48 \%$ for Sinovac, it was $41 \%$ for BioNTech, and the rate of negative sentences was found to be higher for Sinovac (18\%) than for BioNTech (15\%). Considering these results in general, the sentence analyses showed that Sinovac's image was more positive, although the difference was small.

The third question of this study was what feelings users had regarding both brands. As an answer to this question, when an evaluation was made according to sentiments, with a difference of about $7 \%$, the sentiment of "trust" Sinovac outweighed the same sentiment expressed for BioNTech. Although this finding seems to contradict the sentence analysis finding, the evaluation based on sentiments regarding BioNTech, which is of German origin, reflected a general trust in German products. Additionally, when user sentiments were evaluated for both brands, it was seen that negative sentiments such as anger, fear, sadness and disgust were common. 
These results showed that consumers had different perceptions of two different brands, and they had a more positive approach to BioNTech than Sinovac in terms of trust. However, when negative sentiments developed against the two brands are considered in general, the uncertainty about the side effects of vaccines and what they can do on human health in the future, as well as what will happen during the pandemic process, created serious fear, anxiety and anger in the public. From this point of view, it is recommended for the Ministry of Health, for the sake of public peace and health, to provide frequent information on both the pandemic process and the effects and side effects of vaccines, as well as managing the process more effectively by bringing other trustworthy vaccine brands apart from these two brands to the country.

To conclude, the findings of this study contain useful information about the positions of both brands in the minds of the public in Turkey. Companies producing vaccines could use this information to develop a more positive image.

Additionally, the findings show how effective social media is in health as in many other issues. It may be thought that the close results and generally similar results about the two brands that were examined in this study were due to the power of communication on social media. For this reason, the Ministry of Health, specialist doctors and vaccine companies could use social media as an extremely effective tool in terms of creating a positive influence on the public.

\section{Limitations}

The healthy determination of brand image with lexicon-based methods depends on that the sentiment lexicon that is used can sufficiently meet the terms related to a certain field or brand. Accordingly, the positive and negative nature of words can be matched clearly. General lexicons are insufficient in matching the values of the analyzed field words. One of the limitations of this study was the lack of a sentiment lexicon developed in the context of the brand domain. The lack of a lexicon source in the context of the brand image field of Turkish origin has caused the terms to not be adequately represented.

Sharing posts in the social media environment has its own unique structure. This structure includes abbreviations, allusions, the use of irony and emojis used to express emotion. Enough attention is not paid to grammar and spelling rules in the text, and conventional rules are not followed. This was another factor constituting a limitation of the study.

Additionally, the Twitter social network, which was used in the data extraction phase, limits the collection of data with a certain number of collection times and a certain number of tweets. Since the data of the study were obtained under these conditions, this situation constituted the third limitation of the study. Forth limitation of the study is, the study was carried out based on data obtained within one month.

\section{REFERENCES}

Liu, B., (2020). Sentiment Analysis Mining Opinions, Sentiments, and Emotions. United Kingdom: Cambridge University.

Aaker, D. A. (2015). Markalama: Başarıya Ulaştıran 20 Temel ilke. İstanbul: Mediacat.

Akın B., \& Şimşek, U. T. G. (2018). Sosyal Medya Analitiği İle Değer Yaratma: Duygu Analizi İle Geleceğe Yönelim. Mehmet Akif Ersoy Üniversitesi Iktisadi Ve Idari Bilimler Fakültesi Dergisi, 5(3), 797-811.

Atay, L. (2020). Covid-19 Salgını ve Turizme Etkileri. Seyahat ve Otel Işletmeciliği Dergisi 17(1),168-172. Ayan, B. (2016). Sosyal Ağlar Tarihi. İstanbul: Abaküs.

Ayaz, F., (2020). Online Gazetelerdeki Covıd-19 ilaçlarına Ve Aşılarına Yönelik İçeriklerin Analizi.

Aydın, A.F. (2017). Sosyal Medya Kullanımı Ve Kurumsal Markalaşma: Vodafone Örneği. Global Media Journal Tr Edition, 8(15), 320-345.

Azap, A. (2020). COVID-19 Aşıları: Tünelin Ucundaki Işık. Arşiv Kaynak Tarama Dergisi, 29(Özel Sayı 1),

Boon-Itt S., \& Skunkan, (2020). Public Perception of the COVID-19 Pandemic on Twitter: Sentiment Analysis and Topic Modeling Study. (JMIR Public Health Surveill, 6(4): e21978) doi: 10.2196/21978 
Chaudhri, A.A., Saranya, S., Dubey, S. (2021). Implementation Paper on Analyzing COVID-19 Vaccines on Twitter Dataset Using Tweepyand Text Blob. Annals of the Romanian Society for Cell Biology, 25(3) 8393-8396.

Dubey, A. D. (2020). Twitter Sentiment Analysis during COVID19 Outbreak. Available at SSRN: https://ssrn.com/ abstract=3572023. Elektronik Cumhuriyet iletişim Dergisi, 2(2),48-68.

Gülcan, T.D., \& Bayram, P., (2021). Covid-19 Sürecinde Siyasal Katııım: Sosyal Medya Üzerinden Bir İçerik Analizi. International Journal of Economics, Politics, Humanities \& Social Sciences, 4(2),1-11.

He, W., Zha, S.\& Li, L. (2013). Social Media Competitive Analysis and Text Mining: A Case Study in The Pizza Industry. International Journal of Information Management, 33(3), 464-472. http://doi.org/10.1016/j. ijinfomgt.2013.01.001

Indyturk,(2020).Availableat:https://www.indyturk.com/node/146321/haber/koronavir\%C3\%BCs- sosyalmedyaya-nas\%C4\%B1I-yans\%C4\%B1d\%C4\%B1(accessed 14.04.2021)

Insites, (2011). Available at: http://blog.insites.eu/2011/09/14/347-millions-europeans-use-social- networksresults-of-a global-social-media-study/ (accessed 14.04.2021).

Işık, N. (2019). Metin Madenciliği Yöntemleri İle E-Ticaret Markalarına Yönelik Sosyal Medya Yorumlarının Analizi. İstanbul: Yüksek Lisans Tezi. Marmara Üniversitesi Sosyal Bilimler Enstitüsü.

Kamaran H., Rebaz. N., Ramadhan N.P.\& Mohammed R. A. (2020). Twitter Sentiment Analysis on Worldwide COVID-19 Outbreaks. Kurdistan Journal of Applied Research (KJAR) DOI: 10.24017/covid.8.

Karakoç, E. \& Taydaş, O. (2020). Toplumsal Hareketler ve Medya: Kavramlar, Kuramlar ve Tartışmalar içinde; Yeni Toplumsal Hareketler Ve Twitter. Avalabile at: https://www.researchgate.net/publication/345508647_ TOPLUMSAL_HAREKETLER_VE_MEDYA_Kavramlar_Kuramlar_ve_Tartismalar.

Mohammad \& Turney (2013). Crowdsourcing a Word-Emotion Association Lexicon. Available at: http://www. saifmohammad.com/WebDocs/NRCemotionlexicon.pdf (accessed 02.01.2021)

Sattar, N. S, Arifuzzaman, S. (2021). COVID-19 Vaccination Awareness and Aftermath: Public Sentiment Analysis on Twitter Data and Vaccinated Population Prediction in the USA, Applied Sciences, 11(13), June 30, DOI: 10.3390/app11136128

Öke, Ç. Y. (2018). Alternatif Bir Medya Olarak Sosyal Medyanın Yeni Toplumsal Hareketler Üzerindeki Etkisi. Adnan Menderes Üniversitesi Dördüncü Kuvvet Uluslararası Hakemli Dergisi, 1 (1). 52-61

Önden, A., Çallı, M.K., \& Okan, E.Y. (2018) Sosyal Medya'da Marka Krizleri: Duygu Analizi Yöntemi ile Vaka Incelemesi. Journal of Management, Marketing and Logistics -JMML, 5(3), 246-254.

Öztürk, M. F. \& Talas, M. (2015). Sosyal Medya Ve Eğitim Etkileşimi. Journal of World of Turks (Zfwt),

Özüpek M. N. (2004). Kurum İmajında Sosyal Sorumluluk Kurumsal Ve Uygulamalı Çalışma. Doktora Tezi. Konya: Selçuk Üniversitesi, Sosyal Bilimler Enstitüsü.

Ministry of Health, (2020). Available at: https://covid19bilgi.saglik.gov.tr/tr/covid-19-yeni-koronavirus- hastaliginedir (accessed 28.04.2021)

Sanders, A.C., White, R.C., Severson, L.S., Ma, R., McQueen, R., Paulo, H.C.A., Zhang, Y., Erickson, J.S.\&; Bennett, K.P. (2021). Unmasking the conversation on masks: Natural language processing for topical sentiment analysis of COVID-19 Twitter discourse. AMIA Jt Summits Trans/ Sci Proc., 555-564.

Şenol, Y. \& Avcı K. (2019). Sağlık Alanında Kamu Kurumlarının Sosyal Medya Kullanımına Bir Örnek: Sağlık Bakanlığı 2017 Yılı Twitter Hesabının İncelenmesi. Kocatepe Tıp Dergisi, 20, 52-57.

Statista, (2021). Avalabile at: https://www.statista.com/statistics/272014/global-social-networks-ranked-bynumber-of-users/ (accessed 04.11.2021)

Ullah, S., Al-Sehemı. A.G., Klemeš, J.J. Saqıb, S., Gondal, S.M.A., Sidra, S., Akasha, A. Hira, S., Ahmad, M., Muhammad, A. Asıf, S. \& Bokharı, A. (2021). A Review of the Progress of Covid-19 Vaccine Development. Düzce Tıp Fakultesi Dergisi, 23(1),1-23. https//doi.org/ 10.18678/dtfd.890089

Uraltaş, N. T. \& Bahadırlı, L. S. (2012). Elektronik Perakendecilik Ve Bir Reklam Mecrası Olarak Sosyal Ağ 
Vijay, T., Ayan Chawla, A. Balan Dhanka, B. \& Purnendu Karmakar, P. (2020). Sentiment Analysis on COVID-19 Twitter Data. 5 IEEE International Conference on Recent Advances and Innovations in Engineering- ICRAIE 2020 (IEEE Record\#51050) DOI: 10.1109/ ICRAIE51050.2020.9358301

Villavicencio, C., Macrohon, J.J., Inbaraj, X.A., Jeng, J.H. \& Hsieh, J.G. (2021). Twitter Sentiment Analysis towards COVID-19 Vaccines in the Philippines Using Naïve Bayes. Information , 12(5), 204; https://doi.org/10.3390/ info12050204

We Are Social. (20210). https://wearesocial.com/uk/blog/2021/10/social-media-users-pass-the-4-5-billionmark/

Who Coronavirüs, (2021). Available at: https://covid19.wh.int/?gclid=CjwKCAjwiY6MBhBqEiwARFSCPo1mX43Q wCOVRzcvoiTJXSoMBHw1pWPe3uEku2QcL8JXJPtr8cCDxoCmwEQAvD_BwE (accesed 03.11.2021).

Who covid-19 (2021). Available at: https://www.who.int/publications/m/item/draft-landscape-of-covid-19candidate-vaccines (accessed 07.11.2021).

Xue, J., Chen, J., Hu, R., Chen, C., Zheng, C. Liu, X. \& Zhu, T. (2020). Twitter discussions and emotions about covid-19 pandemic: A machine learning approach. Journal of medical internet research, 22 (11).

\section{Beyan ve Açıklamalar (Disclosure Statements)}

1. Bu çalışmanın yazarları, araştırma ve yayın etiği ilkelerine uyduklarını kabul etmektedirler (The authors of this article confirm that their work complies with the principles of research and publication ethics).

2. Yazarlar tarafından herhangi bir çıkar çatışması beyan edilmemiştir (No potential conflict of interest was reported by the authors).

3. Bu çalışma, intihal tarama programı kullanılarak intihal taramasından geçirilmiştir (This article was screened for potential plagiarism using a plagiarism screening program). 